\title{
Evaluation of Molecular Changes of Distal Organs After Small Bowel Transplantation
}

\author{
P. URBAN ${ }^{1}$, M. RABAJDOVÁ ${ }^{1}, \check{S ̆}^{\text {FETERIK }}{ }^{2}$, G. BÓDY ${ }^{1}$, T. GRANDA ${ }^{3}$, M. MAREKOVÁ ${ }^{1}$, \\ J. VESELÁ ${ }^{2}$
}

${ }^{1}$ Department of Medical and Clinical Biochemistry, Faculty of Medicine, Pavol Jozef Šafárik University in Košice, Slovak Republic, ${ }^{2}$ Department of Histology and Embryology, Faculty of Medicine, Pavol Jozef Šafárik University in Košice, Slovak Republic, ${ }^{3}$ Department of Vascular Surgery, East Slovak Institute of Cardiovascular Disease, Košice, Slovak Republic

Received June 30, 2017

Accepted February 20, 2018

On-line May 10, 2018

\section{Summary}

The ischemia and reperfusion of a jejunal graft during transplantation triggers the stress of endoplasmic reticulum thus inducing the synthesis of pro-inflammatory cytokines. Spreading of these signals stimulate immunological reactions in distal tissues, i.e. lung, liver and spleen. The aim of this study was to detect the molecular changes in liver and spleen induced by transplanted jejunal graft with one or six hours of reperfusion (group Tx1 and Tx6). Analysis of gene expression changes of inflammatory mediators (TNF-a, IL-10) and specific chaperones (Gadd153, Grp78) derived from endoplasmic reticulum (ER) was done and compared to control group. The qRT-PCR method was used for amplification of the specific genes. The levels of corresponding proteins were detected by Western blot with immunodetection. Protein TNF-a was in liver tissue significantly overexpressed in the experimental group $\mathrm{Tx} 1$ by $48 \%$ $(p<0.001)$. In the group Tx6 we found decreased levels of the same protein to the level of controls. However, the protein concentrations of TNF-a in spleen showed increased levels in group Tx1 by $31 \%(p<0.001)$ but even higher levels in the group Tx6 by $115 \%(p<0.001)$ in comparing to controls. Our data demonstrated that the spleen is more sensitive to posttransplantation inflammation than liver, with consequent stress of ER potentially inducing apoptosis and failure of basic functions of lymphoid tissue.

\section{Key words}

Apoptosis - Inflammation mediators - Cytokines • Gene expression • Molecular chaperones

\section{Corresponding author}

J. Veselá, Department of Histology and Embryology, Faculty of Medicine, Pavol Jozef Šafárik University in Košice, Šrobárova 2, 04180 Košice, Slovak Republic. E-mail: jarmila.vesela@upjs.sk

\section{Introduction}

Transplantation of small bowel (SBT) is lifesaving treatment for patients suffering complications of intestinal failure (Grant et al. 2015). Short-term graft and patient survival after transplantation of small bowel have improved dramatically during the last few years (Martin-Davilla et al. 2011). Intestinal rejection, if not treated promptly, can rapidly increase in severity, regularly followed by the development of fistulas or anastomosis dehiscence, causing sepsis, resulting in graft loss or death (Garg et al. 2011).

Active defense of intestinal cells from epithelium against pathogenic molecules limit penetration of resident microbes into deeper tissues (Abraham and Medzhitov 2011). The complex network of immune cells and intestinal epithelial cells is maintaining balance between immune tolerance and immune activation at the mucosa. The dysregulation of this balance by acute insult like ischemia/reperfusion or SBT leads to intestinal or system disease (Tóth et al. 2013).

The main post - the complications after transplantation, i.e. pneumonia, intestinal leakage, peritonitis, sepsis, graft-versus-host disease and multiple 
organ dysfunction syndrome have the same cause, recognizing a specific pathogenic mechanism like inflammation and trafficking of neutrophils out of the circulation towards the intestine. This could be adjusted with preservation of the mucosal barrier (Rivera-Nieves et al. 2008, Silva et al. 2016). The understanding of the pathophysiology leading to inflammation complications involves intricate cross-talk among multiple cell populations, hormonal systems, metabolites, and neural signaling along with alterations in oxygen delivery, derangements in oxygen utilization, and modifications in cell phenotypes. After activation, first responder cells of the innate immune system (predominantly macrophages) produce pro-inflammatory cytokines, e.g. tumor necrosis factor (TNF- $\alpha$ ) and interleukin $1 \beta$ (IL-1 $\beta$ ). These early cytokines stimulate the synthesis of other inflammatory mediators and result in the activation of other leukocytes (Mizock 2009). In response to the production of pro-inflammatory cytokines, anti-inflammatory cytokines (e.g. IL-10) are produced to help maintain immune system balance, known as the compensatory anti-inflammatory response syndrome (Lewis et al. 2012). Rapid elevation of inflammatory mediators in the blood released from polymorphonuclear neutrophils $(\mathrm{PMN})$ are often associated with extremely high levels of gene expression of ER derived molecules, these include apoptosis inducing protein Gadd153 (Chop) or antagonistic protein Grp78 (Bip) in the graft. This leads to increased expression in the secondary affected cells of distal tissues (lungs, spleen, liver) (Urban et al. 2012). Lymphoid organs were seriously damaged in earlyphases post-jejunal transplantation. Both the clinical and experimental studies showed dysfunction of immune cells, especially $\mathrm{T}$ lymphocytes. The histological structures of the spleen as well as splenic dendritic cells are seriously damaged in patients with multiple organ dysfunction syndrome (MODS) (Timpone et al. 2013).

The aim of this study was to compare the levels of gene expression changes of inflammatory mediators (TNF- $\alpha$, IL-10), and specific chaperones (Gadd153, Grp78) derived from endoplasmic reticulum (ER), against a control group of samples from distal tissues (liver and spleen tissue) after heterotopic allotransplantation of the jejunal grafts in rats (at 1 and $6 \mathrm{~h}$ of reperfusion). Our results can be used for development of new selective inhibitors of cytokine production (like PI3Kdelta inhibitor) during the post-surgical care of patient what can prolong jejunal grafts viability and increase the survival rates of patients.

\section{Methods}

This animal study was proved by the Committee for Ethics on Animal Experiments at the Faculty of Medicine, Pavol Jozef Šafárik University in Košice, Slovak Republic, and the experimental protocol was proved by the State Veterinary and Food administration of the Slovak Republic No. 854/10-221/3. An animal experiment was performed according to international standards.

\section{Animals}

Adult male Wistar rats were used (mean body weight $250-320 \mathrm{~g}$, total $\mathrm{n}=24,12$ donors, 12 recipients) and kept under normothermic conditions with periodical variation in daylight at $12 \mathrm{~h}$ intervals. $12 \mathrm{~h}$ before surgery they were allowed only to drink water.

\section{Anesthesia}

Donor and recipient animals were anesthetized for graft harvest and transplantation via intramuscular injection of Ketamine $10 \mathrm{mg} / 100 \mathrm{~g}$ (Lure Cedex, France), and Xylazine $1.5 \mathrm{mg} / 100 \mathrm{~g}$ (Greifswald-Insel Riems, Germany). Animals were kept in anesthesia after one hour using $1 / 3$ of total dose of the anesthetic mixture.

\section{Harvest of the graft of the small bowel}

Middle and vertical laparotomy was performed. The harvesting of jejunal graft was done using the technique adapted from Baláž et al. (2003). Jejunal graft was placed in the preservation solution (saline solution, $20 \mathrm{~cm}^{3}$ ) at $4{ }^{\circ} \mathrm{C}$ for $1 \mathrm{~h}$. After the graft harvest, donor animals were killed by exsanguination.

\section{Heterotopic jejunal transplantation with systemic venous} drainage

Middle laparotomy was performed. Graft was removed from refrigerator and placed on the left side of the animal. Aorto-aortal and porto-caval anastomosis were performed, both end-to-side using microsurgery technique (Tóth et al. 2012). When the vascular anastomosis were finished, the blood flow to the graft was reestablished - reperfusion. Oral end of the graft was occluded and the aboral end of graft was reclaimed as jejunostomy. The recipient animals were randomly assigned into two experimental groups - group Tx1 and group Tx6 with specific times of reperfusion $(1 \mathrm{~h}$ and $6 \mathrm{~h})$. 


\section{Postoperative treatment}

Normothermic conditions during and after transplantation were monitored by a micro thermistor. Temperature of individual animals was maintained using a homeothermic blanket. All experimental animals were kept under anesthesia until they were sacrificed. The animals in group Tx1 were sacrificed $1 \mathrm{~h}$ after transplantation by additional overdose of the intramuscularly injected anesthetic mixture. The experimental animals in group Tx6 were sacrificed in the same manner $6 \mathrm{~h}$ after transplantation.

\section{Control group animals}

The control group consists of Wistar rats $(n=12)$ who underwent sham surgical procedure (anesthetics, surgical incision, suture) in the same time periods like experimental group.

\section{Tissue collectioning}

Liver and spleen samples from recipient and control animals were reperfused with RNase free water, weighed and then stored at $-80{ }^{\circ} \mathrm{C}$.

\section{Quantitative RT-PCR}

Total RNA was isolated from samples of liver and spleen parenchyma using fenol-chloroform isolation in combination with isolation kits (Qiagen, Hilden, Germany). The reverse transcription of $2 \mu \mathrm{lmRNA}$ for each sample was done using oligo dT primers (ThermoFisher Scientific, Waltham, USA), and Superscript III (Invitrogen, Carlsbad, USA) according to the manufacturers' instructions. Quantitative PCR was performed on a LightCycler 480 Instrument II (Roche Life Science, Penzberg, Germany). The endogenous control, 18s rRNA was used for normalization of the raw data. The primer sequences for Gadd153, TNF- $\alpha$, Grp78, IL-10 and 18S rRNA are detailed in Table 1. All reactions were carried out in $20 \mu \mathrm{l}$ of mixture containing, $10 \mu$ of SYBR Green PCR Master Mix (2X) (Roche Life Science), $1 \mu \mathrm{l}$ each of forward and reverse primer, $4 \mu \mathrm{l}$ cDNA and $4 \mu \mathrm{l}$ of sterile water.

The thermal cycling conditions were $5 \mathrm{~min}$ at $95^{\circ} \mathrm{C}, 15 \mathrm{~s}$ at $95^{\circ} \mathrm{C}, 10 \mathrm{~s}$ at $60^{\circ} \mathrm{C}$ and $10 \mathrm{~s}$ at $72{ }^{\circ} \mathrm{C}$. All samples were analyzed in triplicate and a six point standard and an internal control were assayed in triplicate on each plate. Relative mRNA expression was determined by the Standard Curve method (Larionov et al. 2005).

Table 1. Localization of specific genes on the chromosome used for primers synthesis (www.genome.ucsc.edu).

\begin{tabular}{|c|c|c|c|}
\hline Name of gene & Chromosomal localization & $\begin{array}{c}\text { Size of gene in bp including } \\
\text { UTRs side }\end{array}$ & $\begin{array}{l}\text { Analysis place of genes } \\
\text { Ex - exon }\end{array}$ \\
\hline Gadd153 & $7 q 21$ & $70.754 .477-70.759 .215$ & $\begin{array}{l}\text { Promotor } \\
\text { Ex4 }\end{array}$ \\
\hline Grp 78 & $1 \mathrm{q} 32$ & $233.978 .360-233.989 .649$ & $\begin{array}{l}\text { Promotor } \\
\text { Ex5 }\end{array}$ \\
\hline $18 S$ rRNA & $12 \mathrm{p} 11$ & $26.669 .896-26.681 .103$ & $\begin{array}{l}\text { Promotor } \\
\text { Ex5 }\end{array}$ \\
\hline$T N F-\alpha$ & 20p11 & $6.936 .373-6.938 .012$ & $\begin{array}{l}\text { Promotor } \\
\text { Ex2 }\end{array}$ \\
\hline$I L-10$ & $13 q 11$ & $52.824 .694-52.828 .560$ & $\begin{array}{l}\text { Promotor } \\
\text { Ex3 }\end{array}$ \\
\hline
\end{tabular}

\section{Western blot analysis}

$100 \mathrm{mg}$ of liver and spleen parenchyma from all experimental animals and control group were homogenized. Proteins from homogenate were separated by sodium dodecyl sulphate-polyacrylamide gel electrophoresis (SDS-PAGE). All samples underwent Western blotting transfer into nitrocellulose membrane
(Trans blot SD semi-dry transfer cell, Bio-Rad). Formed blots were probed with a rabbit polyclonal antibodies against appropriate proteins (GRP78, sc-13968 (78 kDa), GADD153, sc-7351 (30 kDa), IL-10, sc-1783 (20 kDa), TNF- $\alpha, \quad$ sc-8301 (26 kDa) all from Santa Cruz Biotechnology) at room temperature for two hours diluted with phosphate buffered saline (PBS) in ratio 1:500. 
$\beta$-actin antibody (sc-81178, Santa Cruz Biotechnology) was used for normalization of our data as a positive control. After washing with $0.05 \%$ mixture of PBS and Tween 20, the membranes were incubated with a goat anti-rabbit secondary antibody conjugated with horseradish peroxidase (sc-2033, 1:3000, Santa Cruz Biotechnology) for $1 \mathrm{~h}$. All membranes were washed with PBS-Tween 20 and developed with a SuperSignal West Pico Chemiluminescence Substrate (ECL system from Pierce). Intensity of signals was detected by G:BOX visualization system (Syngene). Spot analysis was made using Gene Tools (Syngene). To reduce differences among animals, at least triplicate Western blots for each time point and animal were performed.

\section{Data analysis}

All values are expressed as means \pm SD for normally distributed data. Continuous variables with normally distributed values were analysed using a Student t-test, whereas non-normally distributed continuous data were analyzed with a Mann-Whitney U-test. Statistical analysis was done using software GraphPad INSTAT (GraphPad). $p<0.05$ was considered statistically significant.

\section{Results}

The expression of inflammatory cytokines on $m R N A$ and protein level

The levels of mRNA of cytokine IL-10 in liver parenchyma were reduced in both groups compared to control group (Fig. 1). In the group with one hour reperfusion by $76 \%(\mathrm{p}<0.001)$ and in the group with six hours reperfusion by $46 \%(p=0.01)$. The protein levels of IL-10 in liver parenchyma (Fig. 2) were not significantly changed in both times of reperfusion $(\mathrm{p}>0.5)$.

The levels of mRNA expression of TNF- $\alpha$ gene were in the group Tx1 insignificantly elevated $(p=0.07)$, but in contrast group Tx6 showed insignificantly decreased levels $(p=0.08)$ against the control group (Fig. 1). Protein TNF- $\alpha$ was significantly overexpressed in the experimental group Tx1 by $48 \% \quad(p<0.001)$ compared to controls. The levels of protein TNF- $\alpha$ were decreased in the Tx 6 group when compared to Tx1 group almost about $28 \%$ (Fig. 2). Pro-inflammatory effect of TNF- $\alpha$ is obvious mostly in the first hour of reperfusion after transplantation.

Spleen parenchyma in the group Tx1 expressed decreased levels of IL-10 mRNA by $65 \%(p<0.001)$ compared to controls. Tx6 group showed decreased levels of IL-10 mRNA by $43 \%(p=0.01)$ in comparison to controls (Fig. 3). Surprisingly we found increased protein levels of IL-10 despite the decreasing mRNA levels in both experimental groups in spleen parenchyma. Group Tx1 showed $72 \%(p<0.001)$ and Tx6 $43 \%(p=0.01)$ increase than control group. These data suggests the earlier onset of anti-inflammatory effect of IL-10 during the shorter time of reperfusion.

The mRNA levels of TNF- $\alpha$ showed significant decrease by $24 \%(p=0.05)$ less than controls in $\mathrm{Tx} 1$ group, whereas in Tx6 group there was insignificant increase in mRNA levels by $15 \%(p=0.5)$ against controls (Fig. 3). The protein concentrations of TNF- $\alpha$ showed increased levels in group Tx1 by $31 \%(p<0.001)$ and even higher in the group Tx6 by $115 \%(p<0.001)$ in comparison to controls (Fig. 4).

\section{The expression of chaperones derived from ER on $m R N A$} and protein level

Liver tissue showed significant decreased levels of mRNA for gene Gadd153 against controls in both times of reperfusion, significantly about $89 \%(p<0.001)$ in Tx 1 and $84 \%(p<0.001)$ in Tx6 group (Fig. 1). mRNA data were confirmed by Western blot where we found that protein concentrations of Gadd153 were lower in comparison to control group in both times of reperfusion within the liver. Group Tx1 demonstrated $40 \%(p<0.001)$ decreased levels and group Tx6 showed $44 \%(p<0.001)$ decreased levels when comparing to control group (Fig. 2). This result disproves the occurrence of ER stress in liver parenchyma. In contrast, levels of mRNA for anti-apoptotic gene Grp78 were increased in the group with one hour reperfusion by $18 \%(p=0.05)$ and $48 \%$ $(p=0.001)$ increase for Tx6 in comparison to the control group (Fig. 1). This result was also supported by the protein levels of Grp78 that were significantly two times higher in the group Tx1 ( $p=0.05$ ) (Fig. 2).

Spleen parenchyma showed insignificantly increased levels of mRNA of Gadd153 in the group Tx1 by $34 \%(p=0.08)$ compared to controls followed by even more elevated levels in the group Tx6 by $71 \%(p=0.01)$ in contrast to control (Fig. 3). The levels of protein Gadd153 in the spleen parenchyma were higher in the group Tx1 by $42 \%(p=0.01)$ and four times higher in group Tx6 $(p<0.001)$ against the control group. This fact suggests intense stress of ER (Fig. 4). 


\section{LIVER}

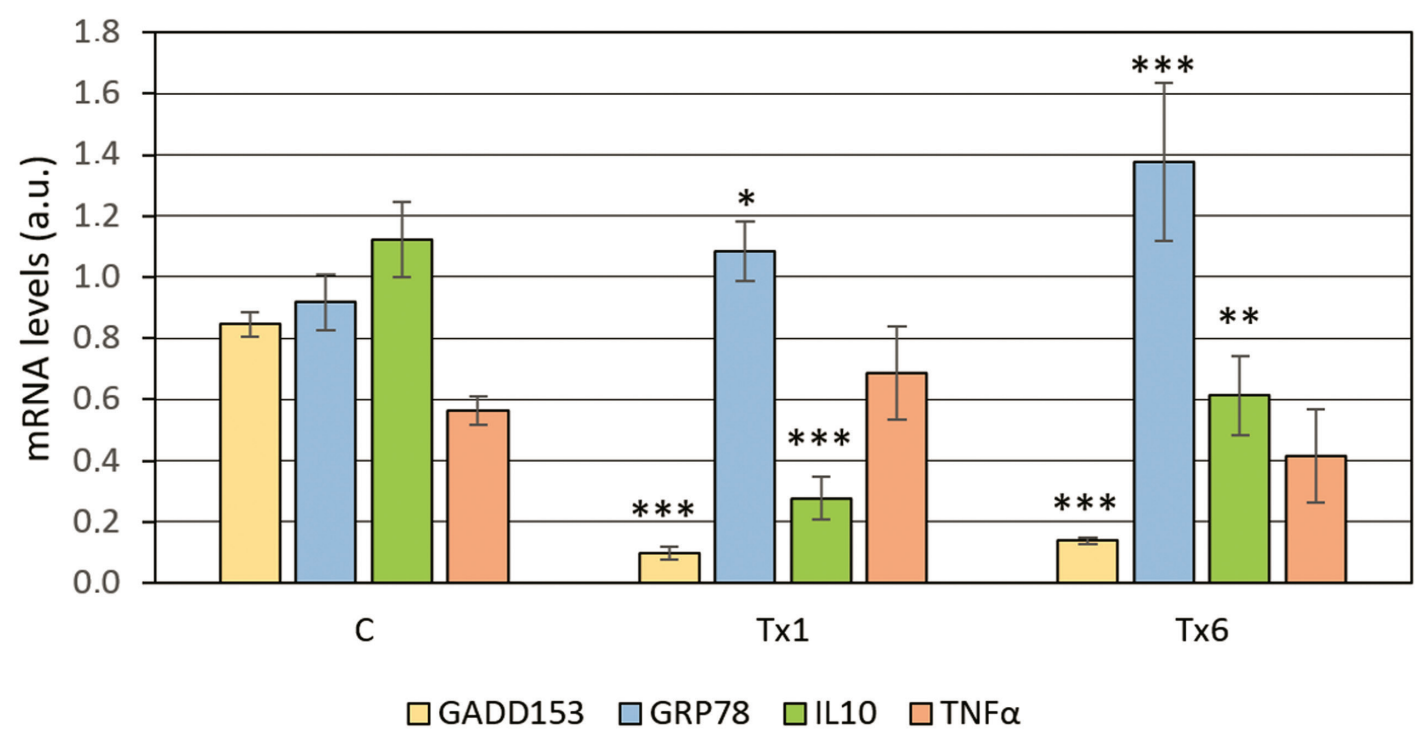

Fig. 1. mRNA levels after transplantation of small intestine with one and six hour reperfusion in liver tissue. The mRNA levels of all detected genes were normalized to the housekeeping gene 18S RNA and compared to controls at the same time interval. All data are presented as average $\pm S D, n=12$ in each experimental group ( $T x 1$ and Tx6), $n=12$ in the control group. * $p<0.05, * * p<0.01$, $* * * \mathrm{p}<0.001-$ statistical significance, $\mathrm{C}-$ control.

\section{LIVER}
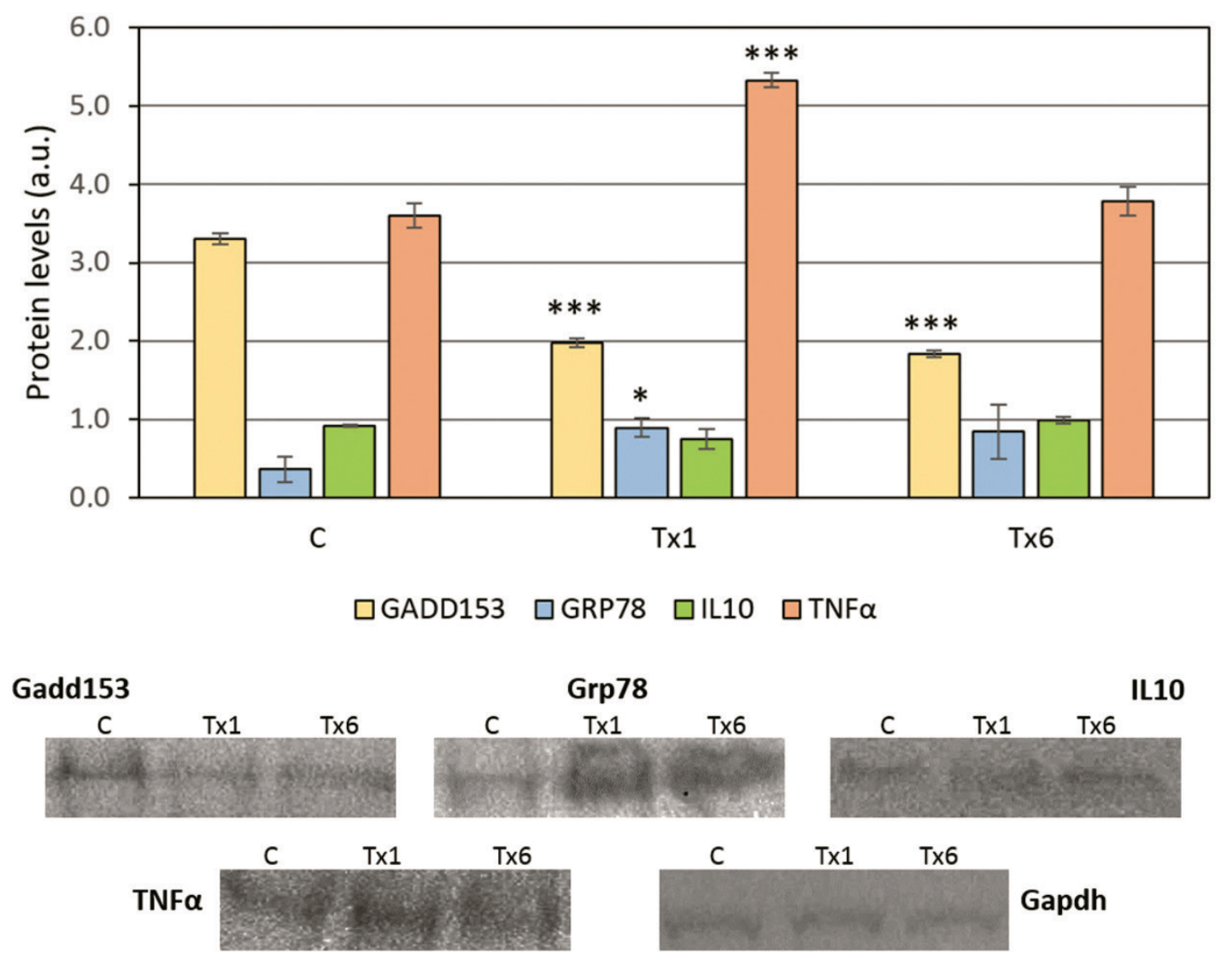

Fig. 2. Protein levels after transplantation of small intestine with one and six hour reperfusion in liver tissue. All protein levels were normalized to $\beta$-actin and compared to controls at the same time interval. All data are presented as average \pm SD, $n=12$ in each experimental group (Tx1 and Tx6), $\mathrm{n}=12$ in the control group. * $\mathrm{p}<0.05, * * * \mathrm{p}<0.001-$ statistical significance, $\mathrm{C}-$ control. 


\section{SPLEEN}

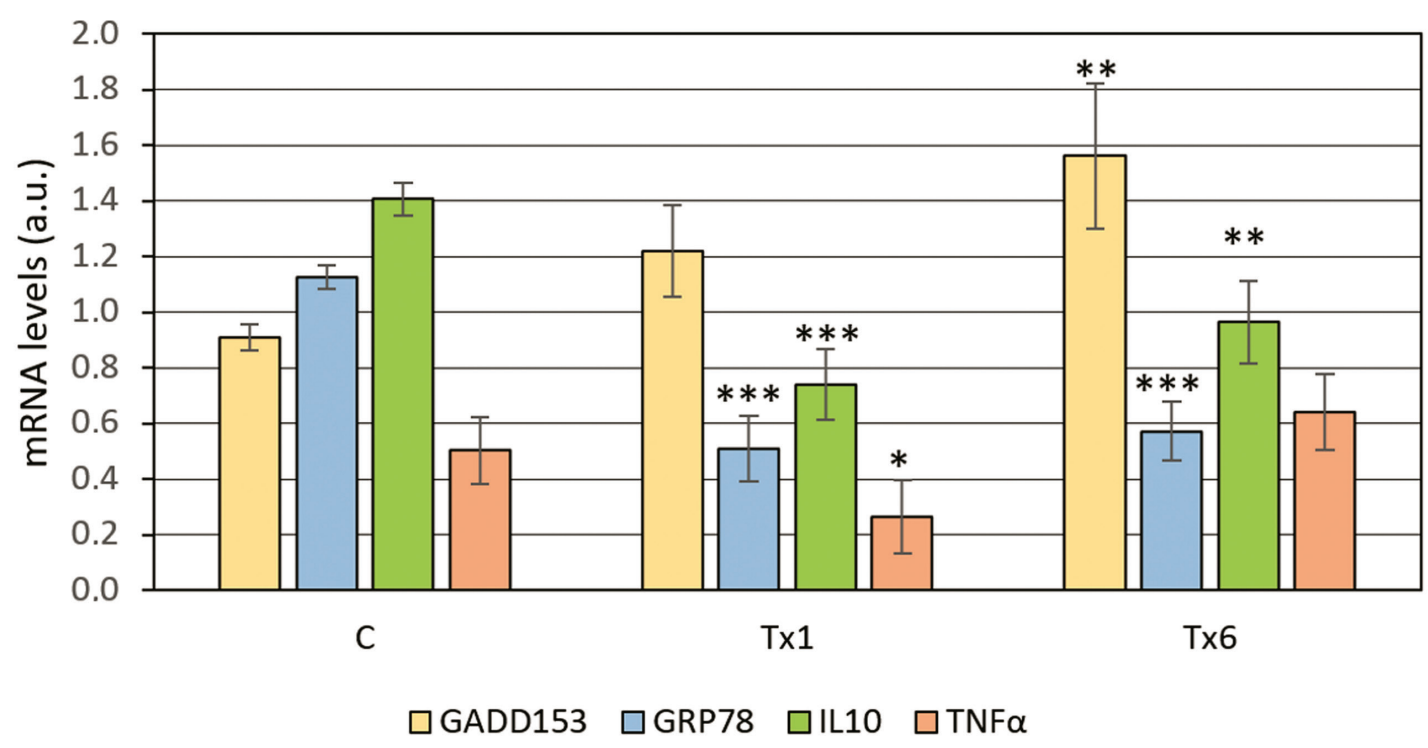

Fig. 3. mRNA levels after transplantation of small intestine with one and six hour reperfusion in spleen parenchyma. The mRNA levels of all detected genes were normalized to the housekeeping gene 18S RNA and compared to controls at the same time interval. All data are presented as average $\pm S D, n=12$ in each experimental group ( $T x 1$ and $T \times 6), n=12$ in the control group. $* p<0.05, * * p<0.01$, $* * * \mathrm{p}<0.001-$ statistical significance, $\mathrm{C}$ - control.

\section{SPLEEN}
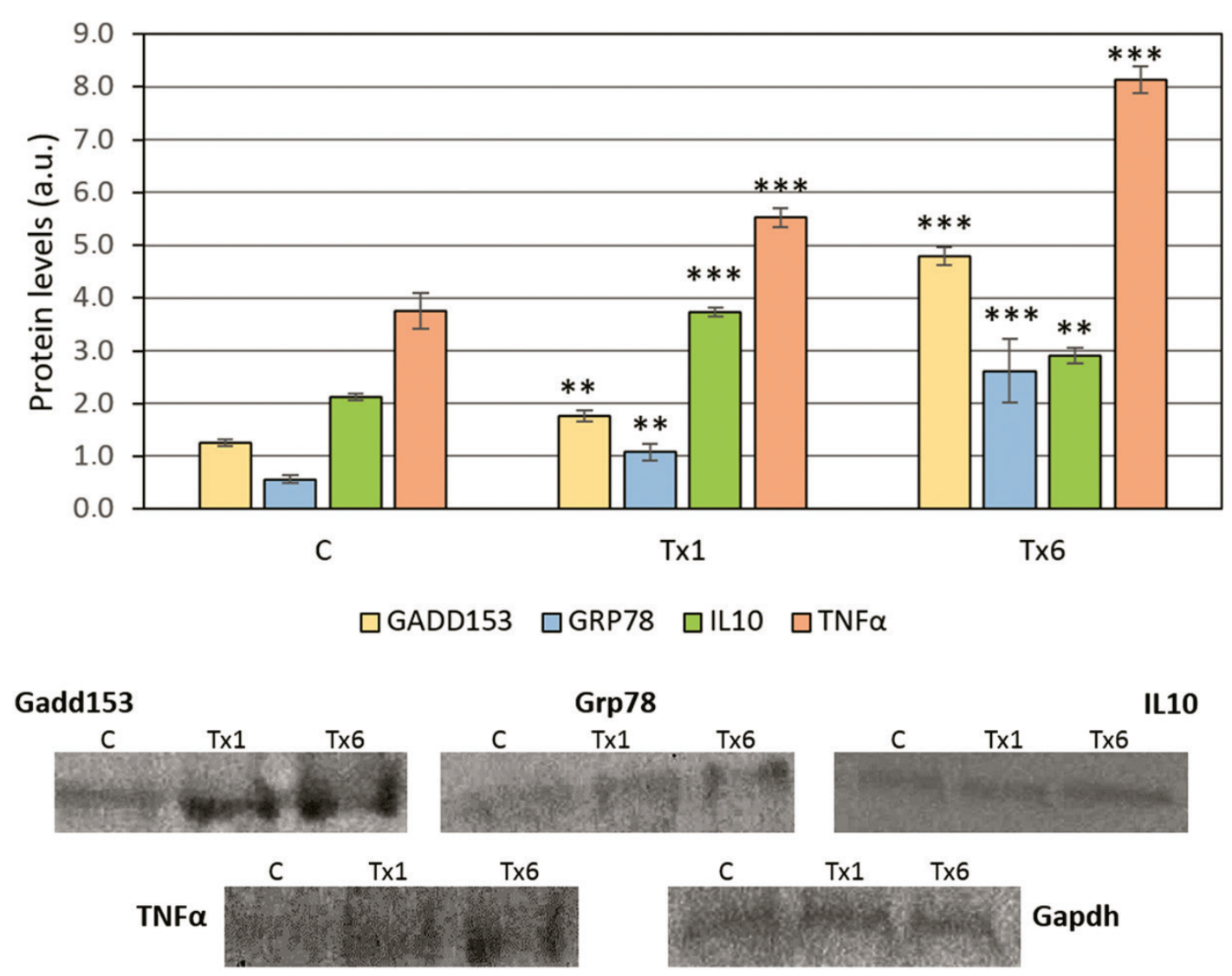

Fig. 4. Protein levels after transplantation of small intestine with one and six hour reperfusion in spleen parenchyma. All protein levels were normalized to $\beta$-actin and compared to controls at the same time interval. All data are presented as average $\pm S D, n=12$ in each experimental group (Tx1 and Tx6), $n=12$ in the control group. ${ }^{* *} \mathrm{p}<0.01, * * * p<0.001$ - statistical significance, $\mathrm{C}-$ control. 
Conversely, we found statistically significant decrease in expression of Grp78 mRNA in both Tx1 and Tx6 group by $62 \%(p<0.001)$ and $54 \%(p<0.001)$ against control group (Fig. 3). Mentioned results are also supported by concentration of anti-apoptotic protein Grp78 (91 \% ( $p=0.01)$ higher than control in Tx1). Group Tx6 demonstrated increase in concentrations by $345 \%$ $(p<0.001)$ higher than controls (Fig. 4). These results confirm the spreading of inflammation induced by jejunal graft transplantation and suggests that immune processes trigger ER stress in spleen parenchyma cells.

\section{Discussion}

Success of jejunal transplantation is affected by the high vulnerability of the small intestine to ischemia/reperfusion injury (Inagi 2010), which inevitably influence the graft. A major part of the enteroendocrine cells population is made up of the group of cells releasing serotonin (Jiang et al. 2003). They also found that jejunal grafts after $1 \mathrm{~h}$ after transplantation express decrease in serotonin positive cell numbers, what was connected with the loss of graft mucosal tissue. During intestinal inflammation, resident monocytes contribute to the recruitment of neutrophils mediated through the production of macrophage derived chemokines. The spreading of inflammation from the jejunal graft was detected also by Tóth et al. (2012). They found the lowest CD163 positive cell number $1 \mathrm{~h}$ after successful connection of the graft to the host circulation, and $6 \mathrm{~h}$ later their number in the jejunal graft had significantly increased. Our previous work (Urban et al. 2012), proved the progress of ER stress signalization in the lungs. The time period of reperfusion after transplantation were set to $1 \mathrm{~h}$ and $6 \mathrm{~h}$ according to previous immuno-histochemical results of Tóth et al. (2013) to achieve correlation with early phases of inflammation.

The presence of growth arrest and DNA damage induced by Gadd153, occur after exposure of the cells to a stressful environment (Guzik et al. 2007). Whole process may result in cell-cycle arrest or cell death. Gadd153 also appears to have an important role in the initiation of apoptosis. Multiple studies (Tanaka et al. 2011) have suggested that critical early events leading to the initiation of apoptosis can be triggered by Gadd153. Ayala et al. (2003) proved an induction of apoptotic process in lymphoid tissues during sepsis. An increased apoptosis has been detected also in the distal organs, such as liver, spleen, colon, ileum, and lymphocytes in septic patients (Hotchkiss et al. 1999, Helfrich and Ison 2015).

The purpose of this study was detection of gene expression changes of inflammatory mediators (TNF- $\alpha$, IL-10) and specific chaperones derived from endoplasmic reticulum (Gadd153, Grp78) and comparing them to control group from the samples of distal tissues (liver and spleen) after allotransplantation of the intestinal graft in rats once reperfused at $1 \mathrm{~h}$ and $6 \mathrm{~h}$.

An effect of jejunal transplantation on formation of ER stress have been well established and characterized by the excessive accumulation of triglycerides in the liver, which is termed as hepatic steatosis (Gao et al. 2012). Specific Grp78 knockout mice exhibited mild fatty liver and liver injury, as well as unfolded protein response (UPR) activation as one would expect from the generally protective role of Grp78 in liver (Chen et al. 2014).

In our recent study, we found the expression of Gadd153 gene, within liver, to be $89 \%$ lower than controls, after transplantation and $1 \mathrm{~h}$ reperfusion. The protein levels demonstrated decreased concentration of Gadd153 in both groups Tx 1 and Tx 6 (about $40 \%$ and $44 \%$, respectively, lower than controls). In combination with the fact that levels of mRNA and protein of Grp78 were significantly rising from one to six hour reperfusion (in mRNA about $18 \%$ and in protein level about $345 \%$ higher values in Tx6 against control), we assumed, this could indicate induction of compensatory processes in reaction to the stress of ER. Increased levels of protein TNF- $\alpha$ were found only in first hour of reperfusion and then restored to the levels of control group, suggesting that liver was less sensitive to the formation of inflammation after transplantation and consequent reperfusion of jejunal graft.

The functional status of spleen and other peripheral lymphoid organs is important for maintaining the balance of immune reaction and inflammatory response. Jiangyang et al. (2011) found that systemic inflammatory response is the direct cause of spleen damage. Splenic dendritic cells down-regulate antigens HLA-DR and CD80, which prefer to induce immuneresistance and play important roles in the immune suppression.

Our results obtained from spleen parenchyma confirm the results of Jiangyang et al. (2011) and suggests that spleen function is significantly affected after small bowel transplantation. We proved the excessive inflammation in both times of reperfusion followed by 
intensive, but regulated, ER stress and UPR. The anti-inflammatory and immunosuppressive functions of IL-10 have been demonstrated to play a protective role in a variety of immune and inflammatory models (Stallion et al. 2002). In the animal models the absence of IL-10 renders the animals more susceptible to inflammatory insults. IL-10 is protective in the LPS/endotoxemia model of sepsis by regulating the inflammatory response through its inhibition of the production of pro-inflammatory cytokines (TNF- $\alpha$, IL-1, IL-6) (Nüssler et al. 2003). Our results proved an increased expression of protein TNF- $\alpha$ together with decreased expression values of anti-inflammatory protein IL-10, what suggest raising inflammation in the spleen and liver.

\section{Conclusion}

An effective approach for the treatment of small bowel post-transplantation complications is yet to exist today. System inflammation spreads and reaches the distal tissues, where triggers strong stress response, which could lead to collapse of whole organism.
Therefore it is necessary to study pathological changes in the secondary affected tissues, such as spleen and liver, closely on the molecular level and suggest possible therapeutically defined protocols for the protection of these tissues. Our results showed that the spleen is more sensitive to the system post-transplantation inflammation than liver, with consequent stress of ER which can cause the induction of apoptosis and failure of basic functions of lymphoid tissue. For better clarification of the activation and progress of the UPR, it is necessary to focus on molecular pathways and mechanism of their regulation, in both early and long term changes. The results can be used for prevention of occurrence of pathological complications after the small bowel transplantation which can prolong the patients' survival.

\section{Conflict of Interest}

There is no conflict of interest.

\section{Acknowledgements}

This research work was supported by grant project VEGA 1/0115/14 and project VEGA 1/0873/16.

\section{References}

ABRAHAM C, MEDZHITOV R: Interactions between the host innate immune system and microbes in inflammatory bowel disease. Gastroenterology 140: 1729-1737, 2011.

AYALA A, LOMAS JL, GRUTKOSKI PS, CHUNG S: Fas-ligand mediated apoptosis in severe sepsis and shock. Scand J Infect Dis 35: 593-600, 2003.

BALÁŽ P, KUDLA M, MATIA I, FRONĚK J, RYSKA M: Model of small bowel transplantation with systemic venous drainage in rats. Ann Transpl 8: 36-38, 2003.

CHEN WT, ZHU G, PFAFFENBACH K, KANEL G, STILES B, LEE AS: GRP78 as a regulator of liver steatosis and cancer progression mediated by loss of the tumor suppressor PTEN. Oncogene 33: 4997-5005, 2014.

GAO Y, SARTORI DJ, LI C, YU QC, KUSHNER JA, SIMON MC, DIEHL JA: PERK is required in the adult pancreas and is essential for maintenance of glucose homeostasis. Mol Cell Biol 32: 5129-5139, 2012.

GARG M, JONES RM, VAUGHAN RB, TESTRO AG: Intestinal transplantation: current status and future directions. J Gastroenterol Hepatol 26: 1221-1228, 2011.

GRANT D, ABU-ELMAGD K, MAZARIEGOS G, VIANNA R, LANGNAS A, MANGUS R, FARMER DG, LACAILLE F, IYER K, FISHBEIN T: Intestinal transplant registry report: global activity and trends. $A m J$ Transplant 15: 210-219, 2015.

GUZIK TJ, HOCH NE, BROWN KA, MCCANN LA, RAHMAN A, DIKALOV S, GORONZY J, WEYAND C, HARRISON DG: Role of the $\mathrm{T}$ cell in the genesis of angiotensin II-induced hypertension and vascular dysfunction. J Exp Med 204: 2449-2460, 2007.

HELFRICH M, ISON MG: Opportunistic infections complicating solid organ transplantation with alemtuzumab induction. Transpl Infect Dis 17: 627-636, 2015.

HOTCHKISS RS, SWANSON PE, FREEMAN BD, TINSLEY KW, COBB JP, MATUSCHAK GM, BUCHMAN TG, KARL IE: Apoptotic cell death in patients with sepsis, shock, and multiple organ dysfunction. Crit Care Med 27: 1230-1251, 1999. 
INAGI R: Endoplasmic reticulum stress as a progression factor for kidney injury. Curr Opin Pharmacol 10: 156-165, 2010.

JIANG HY, WEK SA, MCGRATH BC, SCHEUNER D, KAUFMAN RJ, CAVENER DR, WEK RC: Phosphorylation of the $\alpha$ subunit of eukaryotic initiation factor 2 is required for activation of $N F-\kappa B$ in response to diverse cellular stresses. Mol Cell Biol 26: 5651-5663, 2003.

JIANGYANG L, QIAN L, XIAOHONG W, YI Y, LING L, YI L, JIA Y, MAROTTA M, DEHUA C: Changes of spleen dendritic cells in the terminal stage of multiple organ dysfunction syndrome. Acta Biomed 80: 146-153, 2011.

LARIONOV A, KRAUSE A, MILLER W: A standard curve based method for relative real time PCR data processing. BMC Bioinform 6: 62, 2005.

LEWIS DH, CHAN DL, PINHEIRO D: The immunopathology of sepsis: pathogen recognition, systemic inflammation, the compensatory anti-inflammatory response, and regulatory T cells. J Vet Intern Med 26: 457-482, 2012.

MARTIN-DAVILA P, FORTUN-ABETE J, SAN-JUAN R: Prophylaxis of cytomegalovirus infection in intestinal transplantation. Enferm Infecc Microbiol Clin 29: 60-64, 2011.

NÜSSLER NC, MÜLLER AR, WEIDENBACH H, VERGOPOULOS A, PLATZ KP, VOLK H-D, NEUHAUS P, NUSSLER AK: IL-10 increases tissue injury after selective intestinal ischemia/reperfusion. Ann Surg 238: 49-58, 2003.

MIZOCK BA: The multiple organ dysfunction syndrome. Dis Mon 55: 476-526, 2009.

RIVERA-NIEVES J, GORFU G, LEY K: Leukocyte adhesion molecules in animal models of inflammatory bowel disease. Inflamm Bowel Dis 14: 1715-1735, 2008.

SILVA JT, SAN-JUAN R, FERNANDEZ-CAAMANO B, PRIETO-BOZANO G, FERNANDEZ-RUIZ M, LUMBRERAS C, CALVO-PULIDO J, JIMÉNEZ-ROMERO C, RESINO-FOZ E, LÓPEZ-MEDRANO F, LOPEZ-SANTAMARIA M, MARIA AGUADO J: Infectious complications following small bowel transplantation. Am J Transplant 16: 951-959, 2016.

TANAKA M, ITOH T, TANIMIZU N, MIYAJIMA A: Liver stem/progenitor cells: their characteristics and regulatory mechanisms. J Biochem 149: 231-239, 2011.

TIMPONE JG JR, GIRLANDA R, RUDOLPH L, FISHBEIN TM: Infections in intestinal and multivisceral transplant recipients. Infect Dis Clin North Am 27: 359-377, 2013.

TÓTH Š, JONECOVÁ Z, VARGA J, STAŠKO P, KOVAVALČINOVÁ B, MARETTA M: Mesenteric ischemiareperfusion injury: specific impact on different cell populations within the jejunal wall in rats. Acta Histochem 114: 276-284, 2012.

TÓTH Š, JONECOVÁ Z, VARGA J, STAŠKO P, KOVALČINOVÁ B, MARETTA M, LEŠKO D, VESELÁ J: Immunohistochemical study of jejunal graft mucosa cell populations during the initial adaptation phase in the host body in rats. Acta Histochem 115: 803-809, 2013.

STALLION A, KOU TD, MILLER KA, DAHMS BB, DUDGEON DL, LEVINE AD: IL-10 is not protective in intestinal ischemia reperfusion injury. J Surg Res 105: 145-152, 2002.

URBAN P, BILECOVÁ-RABAJDOVÁ M, MAREKOVÁ M, VESELÁ J: Progression of apoptic signaling from mesenteric ischemia-reperfusion injury to lungs: correlation in the level of ER chaperones expression. Mol Cell Biochem 362: 133-140, 2012. 